\title{
DuPont opens up access to genetics tool
}

[WASHINGTON] In the fight over rights to research tools, biomedical researchers received good news last week, as the National Institutes of Health (NIH), the DuPont Pharmaceuticals Company and the Jackson Laboratory reached historic agreements to free up access for researchers to an important tool used in manipulating mouse genes.

The tool, Cre-loxP, is a powerful technology that allows target genes to be spliced out of specific cells and tissues. The resulting 'conditional mutants' - as well as several other genetically engineered mice created with the technology - are valuable tools for revealing gene function and, ultimately, for understanding human disease.

DuPont, which holds a patent on the technology, had until last week prohibited researchers who have developed and refined Cre-lox mice from sharing them with colleagues, unless the recipients' institutions had signed strict licence agreements. These included promises to give DuPont exclusive first rights to new Cre-lox technologies they developed, and 'reach-through rights' to profits from future discoveries made with the technology.

Dozens of universities had agreed to these terms, but other institutions, including NIH, the Jackson Laboratory in Maine - the largest US breeder of laboratory animals and the University of California, had dug in, saying DuPont's terms were crushing to the research enterprise. Harold Varmus, the NIH director, led the research community's protest, writing to DuPont last year that it was creating conditions that would "seriously impede" further basic research.

But on 19 August, at a cancer genetics meeting at Cold Spring Harbor Laboratory in New York state, Varmus announced that DuPont and NIH had reached what he described as a milestone agreement in the relationship between academics and industry.

\section{German transgenic crop trials face attack}

[MUNICH] The environment minister of the northern German state of SchleswigHolstein is leading opposition to two planned field trials of genetically modified crops in the state. The minister, Rainder Steenblock, says he wants changes in federal law to give the 16 Länder (states) direct participation in the approval of such trials.

Steenblock's intervention is significant because he is a Green Party minister in a state administration governed by a 'Red-Green' coalition between his party and the Social Democrats. A similar coalition might take control of the federal government in next month's general election, and may then put its weight behind the popular opposition in Europe to the introduction of genetically modified crops.

The field trials, which are being carried out by the German company AgrEvo, involve Brassica napus, a species of transgenic rape. They were approved last month by the Robert Koch Institute (RKI) in Berlin, which is responsible for approving such trials throughout Germany.

Steenblock's objections are based on alleged concerns that the transgenes in AgrEvo's rape could be transferred to related crops and weeds, causing ecological problems. He criticizes the RKI for approving the trials without insisting on safety measures, and complains that it adopted a simplified approval procedure for AgrEvo, with no public inquiry, on the grounds that the company is already running similar trials in Lower Saxony.

He cites a case that occurred last spring in the state, in which a genetically modified

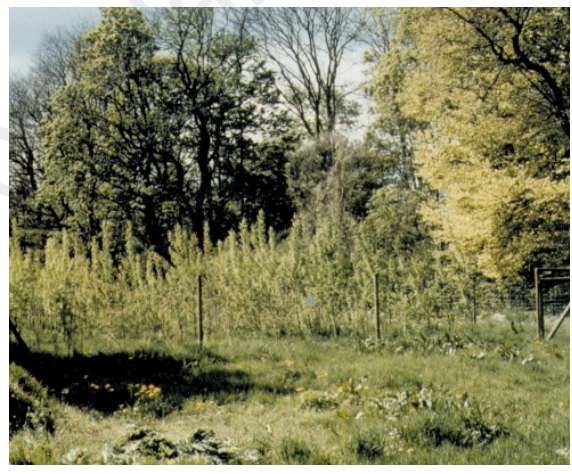

Tree trouble: aspen field trial rang alarm bells in Germany over the safety of transgenic crops.

aspen tree began to bud in its third year of growth, instead of its seventh year as is usual. Had the tree bloomed, he says, it would have presented a serious safety problem because the transgene concerned causes stunted growth. RKI's approval of the trial was contingent on the understanding that the trees would not be allowed to crosspollinate. "This shows how unpredictable genetic engineering can be," says Steenblock.

It is unlikely that the RKI will accept Steenblock's demand for additional safety conditions for trials, however. Ulrich Ehlers, head of the registration office for genetic engineering at the RKI, says the federal authorities were convinced that the experiments were safe.

Even so, AgrEvo is unlikely to avoid a confrontation with Schleswig-Holstein. "If we want to sell these seeds in SchleswigHolstein, we have to test them there," says a company spokesman. Quirin Schiermeier
The company has agreed to make the Crelox technology freely available to $\mathrm{NIH}$ researchers and grant recipients for noncommercial purposes. For academic use, $\mathrm{NIH}$ researchers will be allowed to disseminate Cre-lox materials to colleagues under standard materials transfer agreements. Commercial enterprises will still need to sign commercial licences and pay transfer fees to receive Cre-lox technologies developed in the academic community.

Recipient institutions will need to sign agreements with DuPont only if they plan to further transfer the materials or develop them for the benefit of other commercial users. The new agreements will be a far cry from the old ones: DuPont has dropped its claim to reach-through rights on academic discoveries, as well as its rights of first refusal on new technologies.

Furthermore, the dozens of institutions that had earlier signed the more restrictive agreements with DuPont should not worry, as the company has agreed to make the far more liberal terms in its new agreement with NIH available to them.

Paul Friedman, the president of DuPont Pharmaceuticals Research Laboratories, said in a statement that the company's turnaround reflects its commitment to the "wide dissemination of this valuable technology to the academic community".

$\mathrm{NIH}$ is hoping that other companies will take the hint. "We hope that the agreement will serve as a prototype for how a commercial organization can put a technology into the academic domain" without losing commercial rights, says Maria Freire, the director of NIH's Office of Technology Transfer.

In a move that is just as important for researchers who have confronted a dearth of sources of Cre-lox mice, DuPont has signed an agreement allowing the Jackson Laboratory to collect, breed, preserve and distribute the mice. This is welcome news to scientists such as Jamey Marth, a geneticist at the University of California, San Diego, who helped to develop the Cre-lox system. "People who have generated these agents are no longer going to be inundated with requests," says Marth, because the Jackson Laboratory will supply them on a far larger scale.

University officials hope that the agreement will start a sea change in what has been a growing battle over academic access to tools weighted with intellectual property requirements (see Nature 393, 505; 1998).

"This changes everything," says Terry Feuerborn, the University of California's executive director of technology transfer. "We've needed something like this to demonstrate that there is room for compromise on the exchange of important research materials."
MeredithWadman 